\title{
UJI ORGANOLEPTIK KOPI BIJI SALAK DENGAN VARIAN WAKTU PENYANGRAIAN
}

\author{
Eka Lokaria ${ }^{1}$, Ivoni Susanti ${ }^{2}$ \\ STKIP PGRI Lubuklinggau ${ }^{1}$, \\ ekalokaria87@gmail.com ${ }^{1}$
}

\begin{abstract}
ABSTRAK
Penelitian ini bertujuan untuk melihat pengaruh lama penyangraian terhadap uji organoleptik kopi biji salak banjarnegara (Salacca zalacca var zalacca). Pengaruh perlakuan ditentukan menggunakan metode Rancangan Acak Lengkap (RAL) yang terdiri dari enam perlakuan dan tiga ulangan. Perlakuannya adalah $\mathrm{P}_{0}$ yaitu kontrol, $\mathrm{P}_{1}$ dengan waktu penyangraian 40 menit, $\mathrm{P}_{2}$ dengan waktu penyangraian 50 menit, $\mathrm{P}_{3}$ dengan waktu penyangraian 60 menit, $\mathrm{P}_{4}$ dengan waktu penyangraian 70 menit dan $\mathrm{P}_{5}$ dengan waktu penyangraian 80 menit. Berdasarkan uji anava satu jalur dengan taraf signifikan 5\% menunjukkan hasil yang signifikan yaitu Fhitung $(6,42)>$ F-tabel $(3,68)$, dilanjutkan dengan uji BNT yang memperoleh hasil yang berbeda nyata pada perlakuan $\mathrm{P}_{3}$ (60 menit) dengan angka BNT 2,67. Waktu penyangraian kopi biji salak yang terbaik pada perlakuan $\mathrm{P}_{3}$ dengan waktu penyangraian 60 menit yang memiliki kriteria warna coklat tua, aroma sangat harum, tekstur halus, rasa pahit, dan daya terima sangat suka. Hasil penelitian menunjukkan bahwa semakin tinggi kualitas kopi biji salak maka semakin tinggi daya terima masyarakat terhadap kopi biji salak.
\end{abstract}

Kata Kunci : biji salak banjarnegara, penyangraian, organoleptik

\begin{abstract}
This study aims to see the effect of roasting time on organoleptic tests of banjarnegara zalacca coffee beans (Salacca zalacca var zalacca). The effect of the treatment was determined using the Completely Randomized Design (CRD) method which consisted of six treatments and three replications. The treatments are $P 0$ namely control, $P 1$ with a roasting time of 40 minutes, $P 2$ with a roasting time of 50 minutes, $P 3$ with a roasting time of 60 minutes, $P 4$ with a roasting time of 70 minutes and P5 with a roasting time of 80 minutes. Based on the one way anova test with a significant level of 5\%, it showed significant results, namely $F$ count (6.42)> F-table (3.68), followed by LSD test which obtained significantly different results in the P3 treatment (60 minutes) with BNT number 2.67. The best roasting time for zalacca coffee in P3 treatment with 60 minutes roasting time which has dark brown color criteria, very fragrant aroma, smooth texture, bitter taste, and very acceptability. The results showed that the higher the quality of zalacca coffee the higher the people's acceptance of zalacca coffee.
\end{abstract}

Keywords: salak banjarnegara seeds, roasting, organoleptic 


\section{PENDAHULUAN}

Konsumsi kopi diIndonesia terus meningkat sekitar 36 dimulai tahun 2010 hingga 2014, data ini diperolehAsosiasi Eksportir Kopi Indonesia (AEKI). Berdasarkan data AEKI, Tahub 2010 konsumsi kopi mencapai 800 gram per kapita dengan total kebutuhan kopi mencapai 190 ribu ton. Sedangkan pada 2014, konsumsi kopi Indonesia telah mencapai 1,03 kilogram per kapita dengan kebutuhan kopi mencapai 260 ribu ton (Divinus, 2016)

Seiring dengan terus meningkatnya kosumsi kopi dapat menyebabkan pasokan kopi yang kurang dan dapat menyebabkan kelangkaan kopi karena dengan meningkatnya kebutuhan kopi dari 190 ribu ton sampai 260 ribu ton pertahun maka dari itu diperlukan alternatif pengganti kopi agar dapat mengantisipasi pasokan kopi di Indonesia. Salah satu alternatif pengganti kopi yaitu kopi biji salak dengan memanfaatkan biji salak yang selama ini hanya dikonsumsi daging buah salaknya saja. Menurut Karta (2015) biji salak selama ini belum dimanfaatkan oleh masyarakat, padahal biji salak dapat diolah menjadi produk pangan lokal yang bernilai ekonomis yaitu kopi biji salak.

Saputra (2008) menyatakan bahwa biji salak megandung antioksidan, uji fitokimia senyawa metabolit sekunder yang terdapat pada biji salak yakni senyawa flavonoid, tannin dan sedikit alkaloid. Efek farmakologi senyawa flavonoid di dalam ekstrak biji salak mampu menurunkan kadar glukosa dalam darah. Karta (2015) menambahkan kompleksnya kandungan senyawa yang terkandung di dalam biji salak menjadikan biji salak sebagai bahan yang dapat dimanfaatkan dan menjadi bahan olahan yang dapat dikonsumsi serta memberikan efek farmakologis dan memiliki nilai ekonomis tinggi. Hamni (2014) menjelaskan kopi merupakan minuman yang memiliki aroma dan rasa yang khas yang pada umumnya disukai oleh masyarakat dunia. Kriteria mutu biji kopi yang meliputi aspek, citarasa dan kebersihan serta aspek keseragaman dan konsistensi sangat ditentukan oleh perlakukan pada setiap tahapan proses produksinya terutama tahapan penyangraian.

Teknik pembuatan bubuk kopi secara umum melalui proses pengeringan, penyangraian, pendinginan, dan pengilingan menjadi bubuk kopi (Hamni, 2014). Menurut Nugroho (2009), dalam proses pembuatan kopi proses penyangraian (roasting) merupakan kunci dari produksi kopi bubuk. Pada proses tersebut terjadi pembentukan aroma dan cita rasa khas kopi yang muncul karena perlakuan panas. Berdasarkan pemaparan di atas, maka dalam penelitian ini perlu dilakukan teknik penyangraian dengan durasi waktu yang berbeda sehingga nantinya menghasilakn mutu kopi biji salak yang baik dan disukai masyarakat.

\section{METODE PENELITIAN}

Bahan yang digunakan adalah biji salak banjarnegara. Alat yang digunakan adalah alat pemotong, mesin penggiling kopi, ayakan, sendok, wajan, kompor, pengaduk, stopwatch, nampan, dan thermometer. 
1. Tahap persiapan

Melakukan sortasi biji salak, biji salak terkumpul dipilih dan tahap selanjutnya yaitu pencucian biji salak setelah tahap pencucian, tahap pemotongan biji salak menjadi 2 atau 4 potongan dalam setiap 1 biji salak. Setelah biji salak terpotong menjadi ukuran lebih kecil kemudian tahap selanjutnya yaitu penjemuran atau pengeringan.

2. Tahap penyangraian

Bahan yang sudah kering kemudian dilakukan penyangraian dengan lama waktu penyangraian yaitu antara 40 menit, 50 menit, 60 menit, 70 menit dan 80 menit dan sebagai kontrolnya adalah kopi arabika. Setelah dilaksanakan penyangraian kemudian tahap selanjutnya dilakukan tahap penggilingan dan pengayakan kopi bubuk.

3. Tahap pengujian

Bahan yang sudah tersangrai dan sudah dilakukan penggilingan kemudian dilakukan uji kualitas organoleptik yang meliputi warna, aroma, tekstur rasa, dan daya terima pada setiap bubuk kopi biji salak yang berbeda lama penyangraiannya dan dengan kontrol yaitu kopi arabika.

\section{HASIL PENELITIAN}

\section{Warna}

Warna adalah salah satu parameter fisik yang biasanya pertama kali berinteraksi dengan konsumen.Warna adalah suatu bagian dari makanan atau minuman yang pertama kali di lihat oleh konsumen. Hasil penelitian uji organoleptik terhadap warna dapat dilihat pada grafik 1.

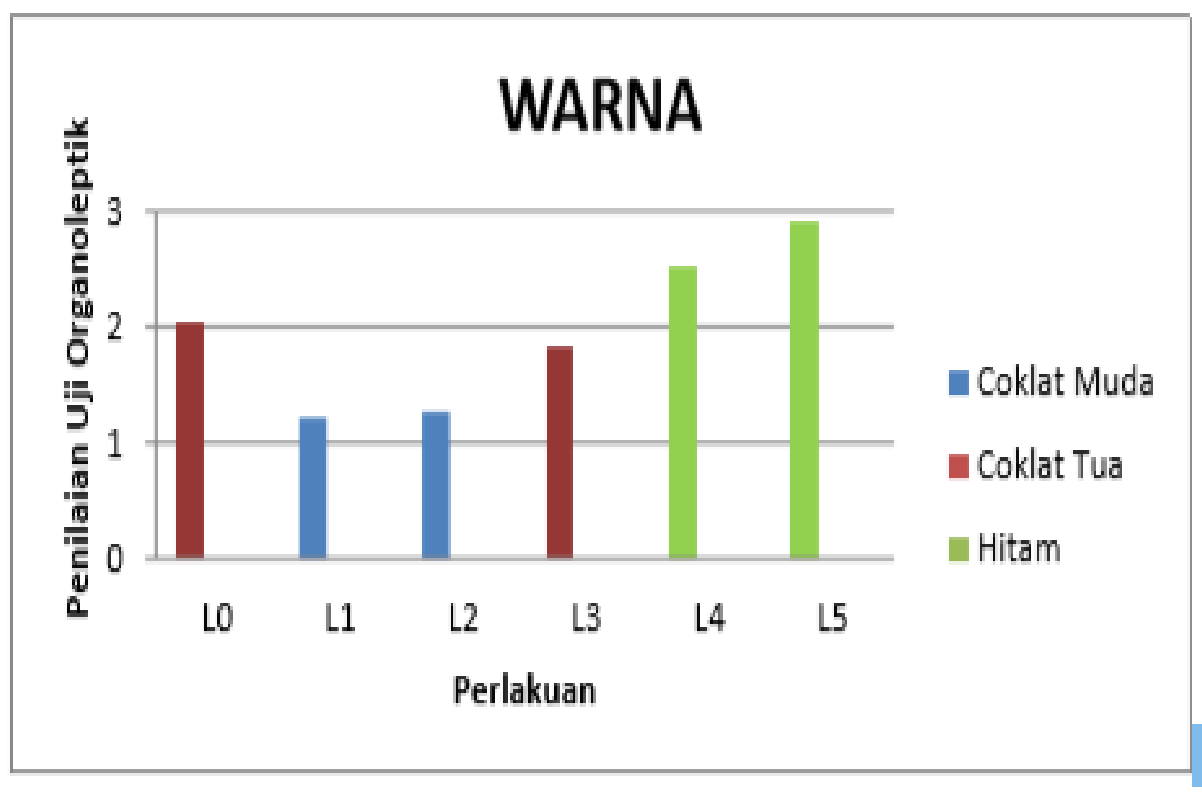

Grafik 1. Warna 


\section{Aroma}

Hasil penelitian uji organoleptik terhadap aroma kopi biji salak dapat dilihat dalam bentuk grafik pada grafik 2 .

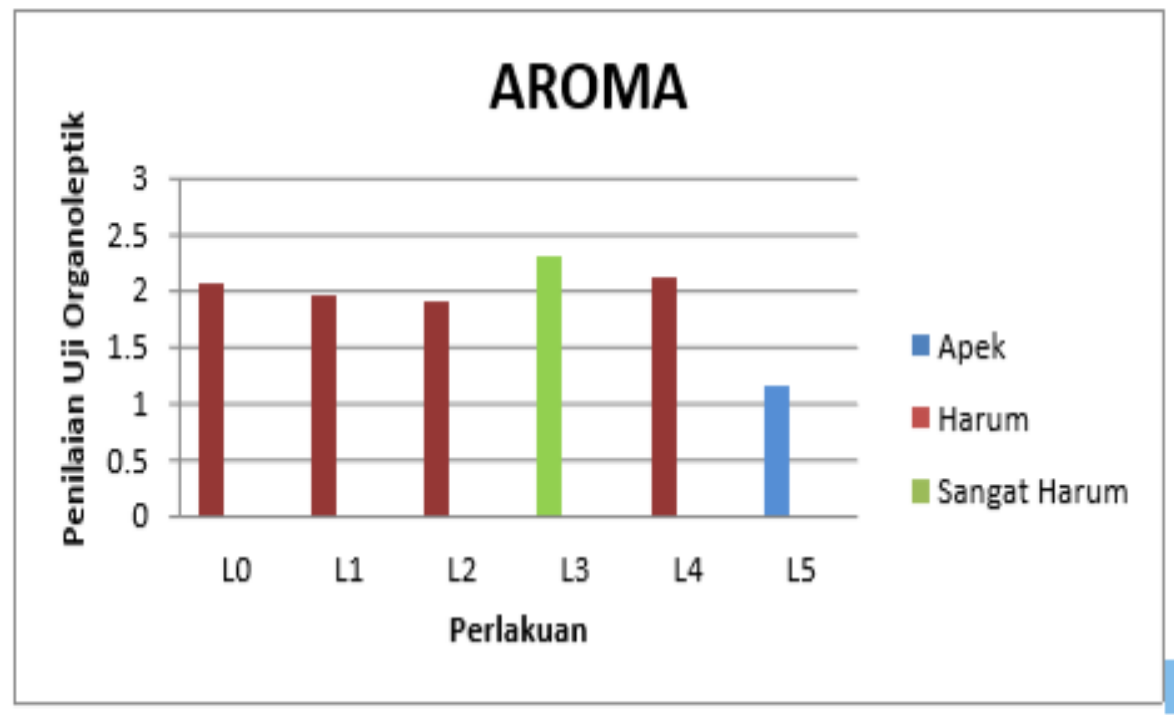

Grafik 2. Aroma

\section{Tekstur}

Hasil penelitian uji organoleptik terhadap tekstur pada kopi biji salak dapat dilihat dalam bentuk grafik pada grafik 3

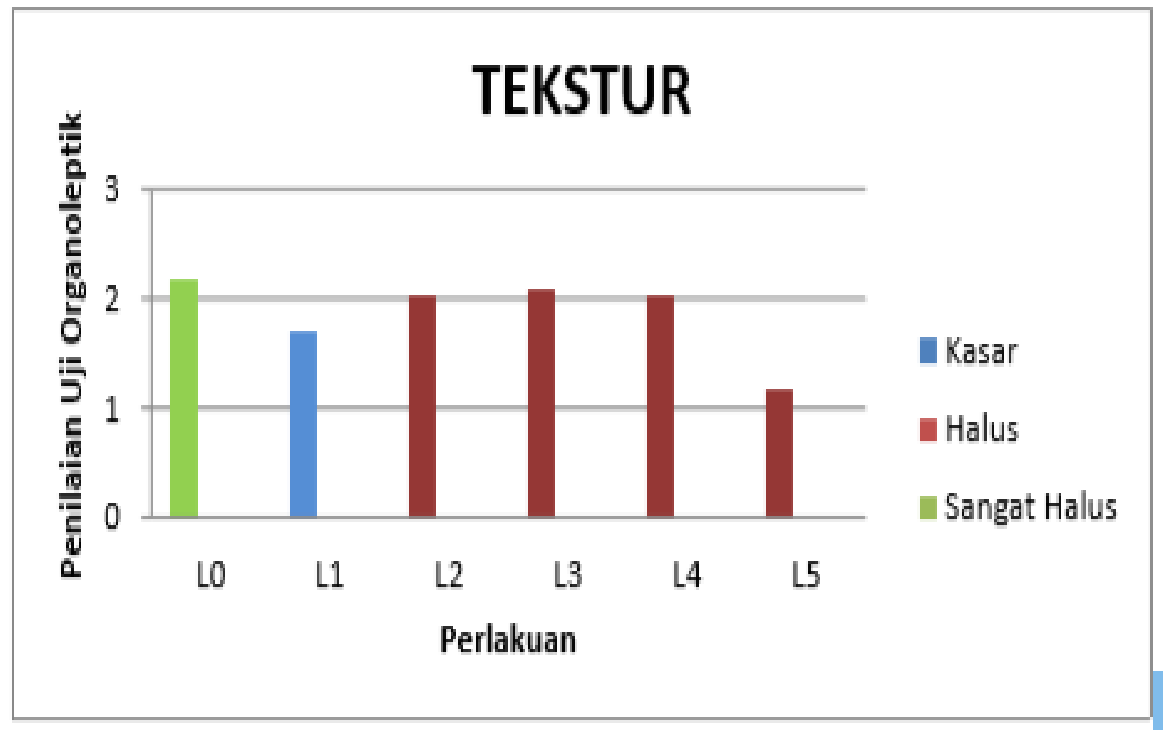

Grafik 3. Tekstur 


\section{Rasa}

Hasil penelitian uji organoleptik terhadap rasa kopi biji salak dapat dilihat dalam bentuk grafik pada grafik 4 .

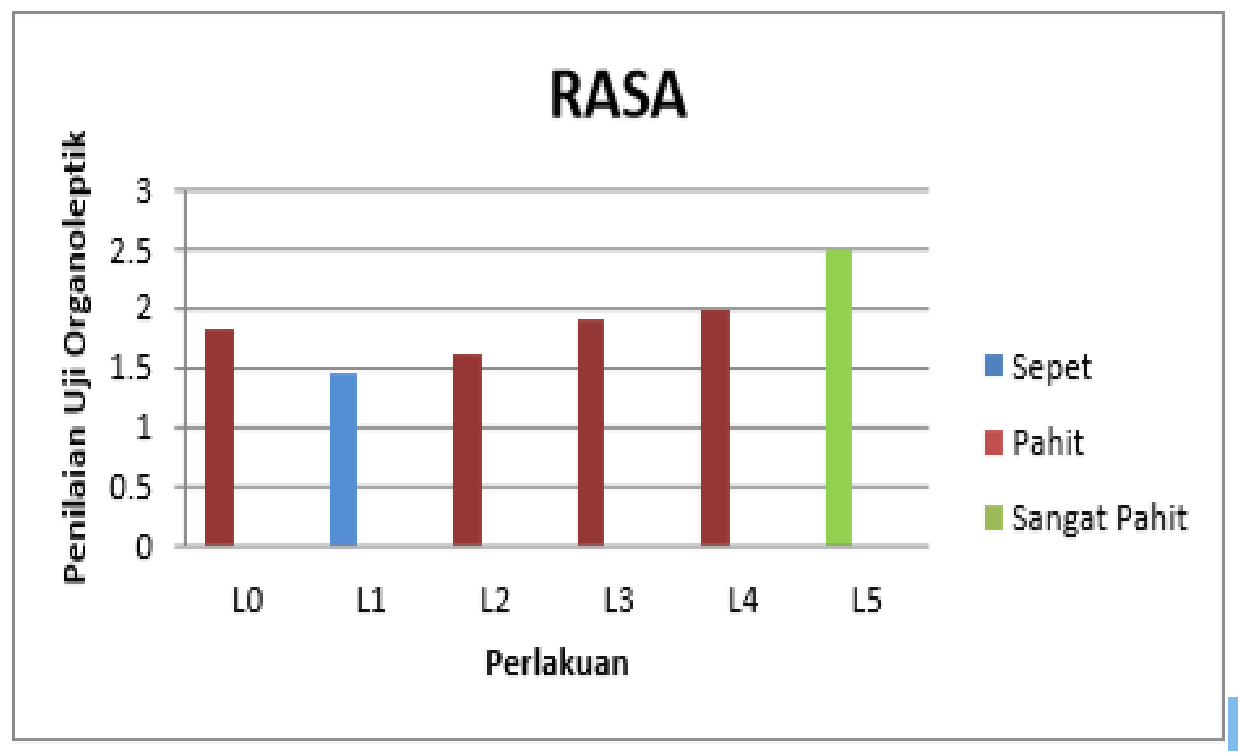

Grafik 4 Rasa

\section{Daya Terima}

Rata-rata uji organoleptik terhadap daya terima kopi biji salak dapat dilihat dalam sebuah grafik pada grafik 5 .

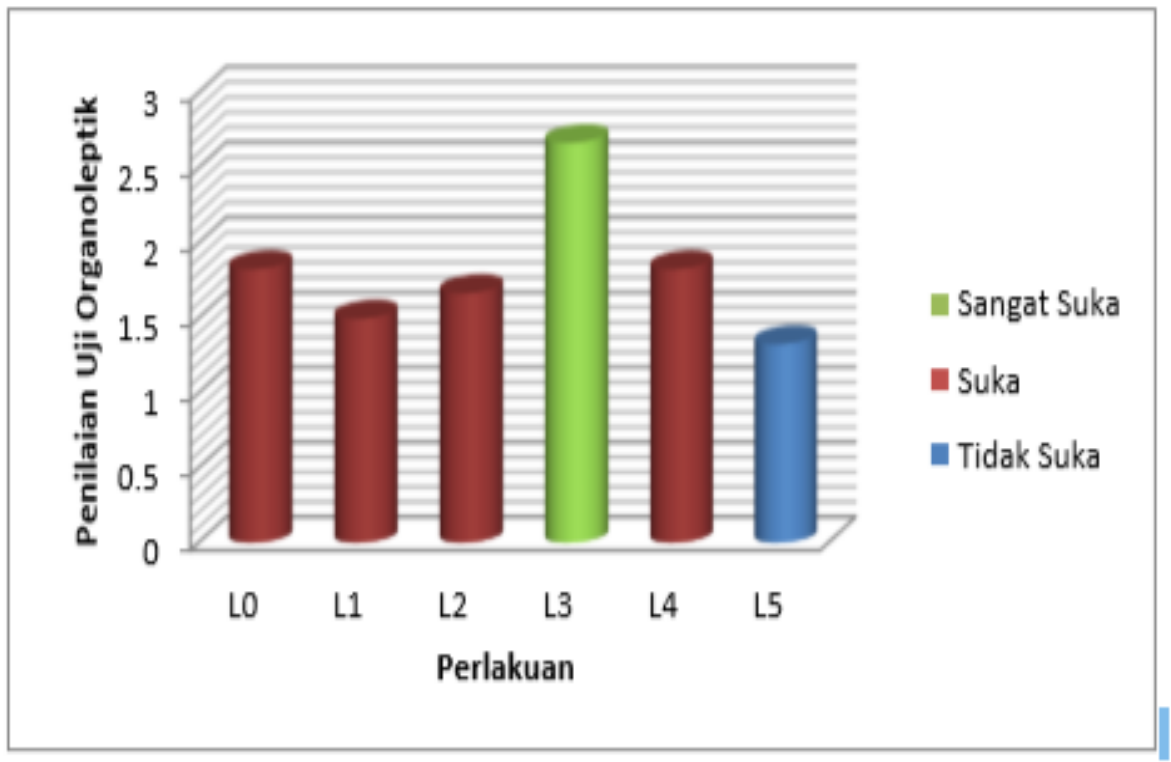

Grafik 5 Daya Terima 
Perhitungan dari uji homogenitas dengan Uji Fisher menunjukkan hasil yang signifikan dengan $(\alpha=0,05)$ nilai $\mathrm{F}_{\text {hitung }(3,94)}<\mathrm{F}_{\text {tabel }(19,00)}$ maka data homogen dan $\mathrm{H}_{0}$ diterima dan $\mathrm{Ha}$ tolak. Hasil perhitungan normalitas dengan uji liliefors pada daya terima juga menunjukkan hasil yang signifikan dengan $(\alpha=0,05) \mathrm{L}_{0}=$ 0,2448333, sedangkan $\mathrm{L}_{\text {tabel }}=0,381$. Karena nilai $\mathrm{L}_{0}<\mathrm{L}_{\text {tabel }}$ maka data berdistribusi normal.Karena data yang di peroleh homogen dan berdistribusi normal maka di lanjutkan dengan uji anava satu jalur. Berdasarkan hasil uji ANAVA, menunjukkan bahwa lama penyangraian memberikan pengaruh beda nyata terhadap daya terima karena $\mathrm{F}_{\text {hitung }}>\mathrm{F}_{\text {tabel }}$. Berdasarkan data ini maka $\mathrm{H}_{0}$ di tolak, yang artinya ada pengaruh lama penyangraian terhadap daya terima kopi biji salak.Berdasarkan perhitungan statistik dengan analisis sidik ragam di peroleh hasil yang dapat dilihat pada tabel 1 .

Tabel 1. Analisis Sidik Ragam

\begin{tabular}{|c|c|c|c|c|c|c|}
\hline Sumber Varian & $\begin{array}{c}\text { Jumlah } \\
\text { Kuadrat } \\
\text { (Jk) }\end{array}$ & $\begin{array}{c}\text { Derajat } \\
\text { Bebas } \\
\text { (Db) }\end{array}$ & $\begin{array}{c}\text { Rata-rata } \\
\text { Kuadrat Rk }\end{array}$ & $\mathbf{F}_{\text {hitung }}$ & $\mathbf{F}_{\text {tabel }}$ & Interprestasi \\
\hline $\begin{array}{l}\text { Antar Kelompk } \\
\text { (perlakuan) }\end{array}$ & 3,22 & 2 & 1,22 & & $\begin{array}{l}3,68 \\
(5 \%)\end{array}$ & Signifikan \\
\hline $\begin{array}{l}\text { Dalam } \\
\text { kelompok } \\
\text { (galat) }\end{array}$ & 2,85 & 15 & 0,19 & 6,42 & $\begin{array}{l}8,36 \\
(1 \%)\end{array}$ & Signifikan \\
\hline Total & 6,07 & 17 & - & - & - & - \\
\hline
\end{tabular}

Hasil penelitian menunjukkan bahwa, lama penyangraian terhadap daya terima kopi biji salak pada setiap perlakuan terjadi perbedaan nyata antara semua perlakuan hal ini diduga adanya perubahan warna, aroma, tekstur dan rasa pada setia perlakuan. Nilai $\mathrm{F}_{\text {hitung }}>\mathrm{F}_{\text {tabel }}$ maka $\mathrm{H}_{0}$ ditolak dan menunjukkan hasil yang sangat signifikan $(\alpha=0,01)$, serta dapat disimpulkan ada perlakuan yang memiliki rata-rata yang bernilai tidak sama (pengaruh lama penyangraian kopi biji salak).

Tabel 2. Hasil Uji BNT

\begin{tabular}{lccc}
\hline \multicolumn{1}{c}{ Perlakuan } & Rata-rata & Perhitungan BNT & Notasi \\
\hline 0 Menit (P0) & 1,83 & $1,83+0,33=2,16$ & $\mathrm{~b}$ \\
\hline 40 Menit (P1) & 1,5 & $1,5+0,33=1,83$ & $\mathrm{a}$ \\
\hline 50 Menit (P2) & 1,67 & $1,67+0,33=2$ & $\mathrm{~b}$ \\
\hline 60 Menit (P3) & 2,67 & $2,67+0,33=3$ & $\mathrm{c}$ \\
\hline 70 Menit (P4) & 1,83 & $1,83+0,33=2,16$ & $\mathrm{~b}$ \\
\hline 80 Menit (P5) & 1,3 & $1,3+0,33=1,63$ & $\mathrm{a}$ \\
\hline
\end{tabular}

Keterangan: Angka-angka didampingi dengan huruf yang sama berarti tidak berbeda nyata 
Berdasarkan tabel.2. di atas menunjukkan bahwa perbedaan lama penyangraian terhadap kualitas organoleptik kopi biji salak berpengaruh terhadap daya terima kopi biji salak kepada masyarakat.

\section{PEMBAHASAN}

Hasil uji organoleptik yang dilaksanakan dengan 30 orang panelis peminat kopi. Berdasarkan hasil uji organoleptik didapatkan hasil yang berbeda pada setiap perlakuan yaitu pada perlakuan L1 (40 menit) memiliki kriteria warna coklat muda, aroma harum, tekstur kasar, rasa sepet dan daya terima suka, pada perlakuan L2 (50 menit) memiliki kriteria warna coklat muda, aroma harum, tekstur halus, rasa pahit dan daya terima suka, pada perlakuan L3 (60 menit) memiliki kriteria warna coklat tua, aroma sangat harum, tekstur halus, rasa pahit, dan daya terima sangat suka, pada perlakuan L4 (70 menit) memiliki kriteria warna hitam, aroma harum tekstur halus, rasa pahit, dan daya terima suka, sedangkan pada perlakuan L5 (80 menit) memiliki kriteria warna hitam, aroma apek, tekstur halus, rasa sangat pahit, dan daya terima tidak suka. Hasil uji organoleptik dan daya terima masyarakat secara umum menunjukkan bahwa karakteristik kopi biji salak yang diminati memiliki karakteristik warna kopi coklat tua, aroma kopi sangat harum, tekstur kopi yang halus, rasa kopi yang pahit dan daya terima masyarakat yaitu sangat suka.

\section{Warna}

Warna pada perlakuan L3 (60 menit) memiliki warna coklat tua, pada perlakuan L4 (70 menit) dan L5 (80 menit) memiliki warna hitam sedangkan pada perlakuan L1 (40 menit), L2 (50 menit) memiliki warna coklat muda.Adanya perbedaan warna pada setiap perlakuan karena adanya perbedaan lama penyangraian yang menyebabkan warna pada setiap perlakuan bedaan. Menurut Putri (2015), faktor lain yang mempengaruhi warna seduhan kopi yang dihasilkan, yaitu karena adanya proses karamelisasi gula yang menyebabkan timbulnya warna coklat tua.

\section{Aroma}

Aroma yang ditimbulkan pada perlakuan L5 (80 menit) adalah apek, perlakuan yang ditimbukan pada perlakuan L1 (40 menit), L2 (50 menit) dan L4 (70 menit) adalah harum, sedangkan perlakuan yang ditimbulkan pada perlakuan L3 (60 menit) adalah sangat harum.Pembentukan aroma kopi karena adanya perlakuan panas. Biji salak mempunyai bau ciri khas buah salak, di tambah dengan proses pemanasan atau penyangraian maka menimbulkan pembentukan aroma yang lebih spesifik. Menurut Nopitasari (2010), aroma dan bau disebabkan oleh adanya senyawa-senyawa yang mudah menguap.terbentuknya aroma yang khas pada kopi disebabkan oleh kafeol dan senyawa-senyawa komponen pembentuk aroma kopi lainnya. 


\section{Tekstur}

Tekstur pada kopi biji salak pada perlakuan L1 (40 menit) adalah bertekstur kasar, tekstur pada pelakuan L2 (50 menit), L3 (60 menit), L4 (70 menit) dan L5 (80 menit) adalah halus, sedangkan tektur pada perlakuan L0 (kontrol) adalah sangat halus. Menurut Nugroho (2009), lama proses penyangraian menyebabkan biji salak yang disangrai akan semakin rapuh sehingga mudah hancur dan menjadi serbuk halus ketika digiling.

\section{Rasa}

Rasa kopi pada perlakuan L1 (40 menit) adalah sepet, rasa kopi pada perlakuan L2 (50 menit), L3 (60 menit) dan L4 (70 menit) dominan mimiliki rasa pahit sedangkan pada perlakuan L5 (80 menit) dominan memiliki sangat pahit. Hal ini dapat terjadi karena pengaruh dari proses lamanya penyangraian. Semakin lama penyangraian maka kopi akan semakin hitam dan semakin sangat pahit. Menurut Nopitasari (2010), timbulnya rasa pahit pada ekstrak kopi disebabkan adanya kandungan mineral bersama dengan pemecahan serat kasar, asam khlorogenat, kafein, tannin, dan beberapa senyawa organik dan anorganik lainnya.

\section{Daya Terima}

Berdasarkan uji Anava satu jalur yang dilakukan terhadap daya terima kopi biji salak dengan hasil $F_{\text {hitung }}>F_{\text {tabel }}(\alpha=0,05)$ yang menyatakan bahwa terdapat pengaruh lama penyangraian terhadap daya terima masyarakat terhadap kopi biji salak. Hal ini menunjukkan bahwa dengan adanya perbedaan lama penyangraian mempengaruhi minat masyarakat terhadap kopi. Hasil pengamatan yang dilakukan menggunakan angket terlihat adanya pengaruh lama penyangraian terhadap daya terima kopi biji salak. Hal tersebut dapat dilihat dari rata-rata daya terima kopi biji salak dengan rata-rata daya terima kopi kontrol. Pada kontrol dilakukan penyangraian sesuai penyangraian kopi pada umumnya, sedangkan pada 5 perlakuan lainnya dilakukan variasi lama penyangraian yang berbeda, yaitu 40 menit, 50 menit, 60 menit, 70 menit dan 80 menit. Daya terima, pada perlakuan L3 (60 menit) dengan lama penyangraian 60 menit memberikan pengaruh paling baik kepada daya terima masyarakat terhadap kopi di banding perlakuan yang lain. Menurut Divinus (2016), penyangraian yang dilakukan terlalu lama akan menyebabkan penurunan kadar air dan persen kelarutan dan menghasilkan warna yang semakin gelap selain memiliki warna yang gelap juga memiliki aroma dan rasa yang gosong

\section{SIMPULAN}

Berdasarkan hasil penelitian yang telah di lakukan dapat di simpulkan bahwa ada pengaruh lama penyangraian terhadap kualitas organoleptik dan daya terima produk kopi biji salak terhadap masyarakat. Berdasarkan uji anava satu jalur dengan taraf signifikan 5\% menunjukkan hasil yang signifikan yaitu Fhitung 
$(6,42)>$ Ftabel $(3,68)$, dilanjutkan dengan uji BNT yang memperoleh hasil yang berbeda nyata pada perlakuan $\mathrm{P}_{3}$ (60 menit) dengan angka BNT 2,67. Waktu penyangraian kopi biji salak yang terbaik pada perlakuan $\mathrm{P}_{3}$ dengan waktu penyangraian 60 menit yang memiliki kriteria warna coklat tua, aroma sangat harum, tekstur halus, rasa pahit, dan daya terima sangat suka. Hal ini menunjukkan bahwa semakin tinggi kualitas kopi biji salak maka semakin tinggi daya terima masyarakat terhadap kopi biji salak. Penelitian kedepannya perlu dilakukan uji lebih lanjut mengenai jenis antioksidan yang terkandung dalam biji salak dan hendaknya masyarakat dan pemerintah lebih memperhatikan dan menggunakan produk lokal yang berpotensi dan bermanfaat.

\section{DAFTAR PUSTAKA}

Divinus, S, (2016). Pengaruh waktu penyangraian terhadap sifat fisikokimia dan organoleptik bubuk biji salak pondoh (Salacca edulis). Master skripsi, katolik widya mandala Surabaya diakses dari http://repository.wima.ac.id/8711/1/ABSTRAK.pdfUniversitas

Hamni, A. Ibrahim, Gusri Akhyar. Harun \& Suryadiwansa. (2014). Impementasi system gasifikasi untuk pengeringan biji kopi. Jurnal Mechanical, 5 (1), 21-25. Artikel online tanpa DOI

Karta, I.W. Susila Eva, L.A.N.K, Mastra, IN, \& Dikta Asnawa. (2015). Kandungan gizi pada kopi biji salak (Salacca zalacca) produksi kelompok tani abian salak desa sibetan yang berpotensi sebagai produk pangan local berantioksida dan berdaya saing. Jurnal virgin, 1(2), 123-133. Artikel online tanpa DOI

K.W. Nugroho Joko, Lumbanbatu, Juliaty \& Rahayoe, Sri. (2009). Pengaruh suhu dan lama penyangraian terhadap sifat fisik-mekanis biji kopi robusta. ISSN 2081-7152. Prosiding gelar teknologi PARTETA. Diakes dari https://repository.ugm.ac.id/33122/1/a20_Joko_Nugroho.pdf

Nopitasari, I. (2010). Proses pengolahan kopi bubuk (campuran arabika dan robusta) serta perubahan mutunya Selma penyimpanan. Master skripsi, IPB diakses dari http://repository.ipb.ac.id/jspui/bitstream/123456789/62228/1/F10ino.pdf

Putri, Rinjani., M. (2015). Pengaruh pemberian seduhan kopi robusta ( Coffea canephora var.robusta) Terhadap Ketebalan Dinding corpus vertebrae tikus strain wistar jantan (Rattus novergicus Strain wistar). Master skripsi diakses dari http://eprints.umm.ac.id/33041/1/jiptummpp-gdl-mitharinja43520-1-pendahul-n.pdf

Saputra, E., (2008). Kopi. Yogyakarta: Harmoni. 